\title{
THE ANALYSIS OF FLOUTING OF CONVERSATIONAL MAXIMS ON THE MAIN CHARACTERS IN "MOANA" MOVIE
}

\author{
DiniNurfarwati $^{1}$, SitiNurAnisa $^{2}$, RasiYugafiati $^{3}$ \\ ${ }^{1}$ IKIP Siliwangi \\ ${ }^{2}$ IKIP Siliwangi \\ ${ }^{3}$ IKIP Siliwangi \\ 11dininurfarwati.dn@gmail.com, ${ }^{2}$ chacha.anisa49@yahoo.com, ${ }^{3}$ tanya.rasiyugafiati@gmail.com
}

\begin{abstract}
This study focuses to analise the flouting of conversational maxims which are found in Moana movie. The study uses mix method. There are four of maxims can be revealed. The first is maxim relevance. The reasons of maxim relevance are:"The Maui's responses do not appropriate to Moana's statements" and "Moana's response does not appropriate to Maui's statement". The second is maxim manner.The reason of maxim manner are: "Moana's statements do not clear", "Maui's response does not appropriate to Moana's statement", and "Maui's statement does not clear". The third is maxim quantity. The reasons of maxim quantity are: "The Maui's responses do not appropriate to Moana's statements", "Moana's responses do not appropriate to Maui's statement", "Maui's statement is flouting the maxim", and "Moana's steatment is flouting the maxim". The forth is maxim quality. The reason is "Maui's responses contain lies". that among 4 types of maxim in conversation between the main character, Moana and Maui in Moana movie, the maxim of relevance was the most identifiable type. 16 conversations cover $38,1 \%$. The second is the maxim quantity. 14 conversations cover $33,3 \%$. The third is the maxim manner. 10 conversation or covers $23,8 \%$. The maxim quality gets 2 conversations and covers $4,8 \%$. The conclusions are the conversation related to ask to do something, be success in doing something, give surprise and do not want something bad happened to the friend.
\end{abstract}

Keywords: Conversational Maxims, Flouting Maxims, Movie

\section{INTRODUCTION}

As defined by Maeinborn (2011) in (Andresen, 2013) that spoken language is one of the most basic types of human communication. We converse to each other to convey information about things and work together. In different cultures there are rules and norms that make people understand each other, and these rules apply not only to the way language is used. There are also rules and norms that govern how the conversation should be done. A set of rules for what constitutes a successful conversation between speakers is called the saying of a conversation. This Maxims was introduced by philosopher Grice (1975) in (Andresen, 2013).

Philosopher Grice (1975) (Sobhani \& Saghebi, 2014), who propose a conversational theory consisting of the principle of collaboration (hereinafter referred to as $\mathrm{CP}$ ): "Make your conversation contribute as you wish, to the stage in which it occurs, to the aims or direction of the conversation wherein you are engaged" (Sobhani \& Saghebi, 2014). This principle is supported by four maxims. These are maxim of quantity, quality, relevance, and manner as defined Cook (1989) cited in (Robiatul, 2016). Maxim quantity specifies that the speaker must inform his or her contribution when necessary. In other word, the speaker does not give contribution as more informative or less informative as is necessary. Maxim of quality assumes that speakers speak the truth, not saying anything that fits proof. Next maxim relevance means 
that a speaker has to be relevant with the theme under discussion. The last maxim of manner is that the speaker should avoid the ambiguity of the term, avoid ambiguity, short and neat.

According to Yule (1996) in (Winiharti, 2009) This is a pragmatic imperative in conversation, which is then described in four maxims:

Quantity: (a) Build your contribution informative required (for current exchange purposes); (b)

Do not make your involvement more informative than necessary.

Quality: make sure your contribution is true; (a) Do not speak what you think is wrong; (b) Do not say there is not enough evidence.

Relation: Be relevant

Manner: Be Simple; Avoid darkness of appearance, keep away from ambiguity, shorten (avoid unnecessary verbosity), be neat.

Most people fail to follow the saying either intentionally or unintentionally. Two of such failing to observe maxims are: violation and flouting of maxims. This study focuses to the flouting maxim. Sometimes people talk without fulfilling their maxims. They scoff at them for a reason. As defined Paltridge (2006) in (Jorfi \& Dowlatabadi, 2015) also believes that when someone is flouting a maxim, they are not deliberately trying to deceive or mislead their interlocutors, but they deliberately do not follow the maxim so that the other person understands the set of other meanings.

For example of flouting maxim relation:

- Father to daughter at family dinner: Any news about the SAT results?

- Daughter: Ice-cream anyone?

Daughter is reluctant to talk about SAT issues either because she feels her parents are too disturbing or because she has no good information (her score is extremely low). To delay the discussion on the subject, he shifts the conversation to a "safe" topic, such as an offer to serve ice cream.

In this study, the researchers are interested in using movies entitled "Moana", which released on 23 November 2016. The researcher chooses "Moana" movie as an object of study for some reasons. First, this movie is interesting because the theme of this movie tell about ethnic people. Second, this movie very humorous because of the funny of two main characters. Third, the researchers find many conversations which are irrelevant in Moana movie. Thus, the researchers interested to examine the flouting maxim in moana movie.

\section{Conversational Maxims}

In general social and linguistic sciences, especially the principles of cooperation, illustrate the manner of people interrelate with each other. Interaction is there a conversation that is one of the parties as a speaker and the other as a listener. When a conversation is occur among a speaker and a listener, there is a simple thing form of communication in which a speaker speaks and a listener makes his / her respond.

Grice as quoted by Grundy (2013) in (Robiatul, 2016) states that when we speak, we try to be cooperative in the upliftment of these ideas, which he calls the "cooperative principle". One way to be cooperative is for a speaker to provide as much information as you expect.The cooperative principle is a philosophy formulated by Herbert Paul Grice in William James Lectures and presented at Harvard University on 1967. It was first published by Harvard 
University Press in a journal entitled "Logic and Conversation" on 1975 states: "Make your conversation contribution as desired, at a stage where it happens with the goal or the way of the conversation wherein you are involved" Grice (1975: 45) cited in (Robiatul, 2016).

Grice (1975) in (Robiatul, 2016) suggests that participants in the communicative exchange be guided by a principle that determinehow languages with maximum efficiency and impact are used to achieve rational communicationss. Grice formulates guidelines for efficient and effective language use in conversations. These guidelines known as talking maxims. It can be underlined that Grice introduces quantity, quality, relationships and ways as a category.

As define Thomas (1995) cited in (Andresen, 2013) The cooperative principle include four conversational maxims, as suggested by Grice. The first maxim is the Maxim of Quantity, which says "Make your involvement as informative as is required" and "Do not make your involvement more informative than is required". The second maxim is the Maxim of Quality, which states that the person making an utterance should not say something that they do not believe to be true or for which they lack adequate evidence. The third maxim is the Maxim of Relation, which states that the utterance should be relevan. The fourth maxim is the Maxim of Manner, which states that the utterance should be "brief, be orderly, avoid ambiguity, and keep away from obscurity of appearance.

\section{Flouting the Maxim}

Flouting the maxim is defined as when speaker do not appear to follow the maxim but expect the listener to generated the implication, not taking the words at the worth appearance (Winiharti, 2009). Based on the theory that the speaker wants the listener to understand the purpose of what is delivered, even though it is not appropriated maxim rules.

\section{Flouting Quantity}

Flouting quantity is when the speaker gives less or more information than is required. That means it does not match the information or questions make the involvement as informative as required. If the information given is excessive, it will cause flouting quantity.

Example :

Moana : Yeah... We did it!

Maui : Congratulations, on a being dead, curly. You surprise me. But I still no taking that thing back. You want to get to Te Fiti. You have to gothrough the whole oceans and bad. Not to mention Te Ka. Lava monster. Ever defeat lava monster.

\section{Flouting Quality}

Flouting quality is define as saying something which does not represent what they think. The contribution of the conversation is not true or lies and the speaker will say the lack adequate evidence.

Example :

Moana : Get this away.

Maui : Hah .. hey .. hey... I'm Demigod, okay? Stop that, I will smack you.You want to get smote. Listen, that thing does not give you power to create life. It's a homing weaken of death. If you don't put it away bad thing will come for it. 


\section{Flouting Relevance}

Flouting relevance is the hearers are expected to imagine statement that is not said as the answer to the question. Thus, the interlocutor must be understand about what the speaker say.

Example :

Maui : What can I say, except we're dead soon. We're dead soon.

Moana : Can't you at least try?

Maui : Giant hook. Hey, it's okay... it's okay. We're dead soon.

\section{Flouting Manner}

Flouting manner is done by being difficult to understand and often exclude a third party.This flouting maxim occurs when the way of expressing the expression by using an unclear expression, the sentences is ambigous, prolixity, and not unorganized sentences.

Example :

Maui : Stay.

Moana : What ? No? I'm... I'm the one who...

\section{Movie}

Movie is consdered in important ar form, a populr source of entertainment, and a powerful tool for educating or indoctrinating people (Robiatul, 2016).

Moana is 2016 American 3D computer-animated musical fantasy adventure movie created by Walt Disney Animation Studios and releas by Desney Pictures. The movie introduce Auli'i Cravalho as Moana and characteristic the voices of Dwayne Johnson, Rachel House, Temuera Morrison, Jemaine Clement, Nichole Scherzinger, and Alan Tudyk. The movie tells the tale of Moana, the iron-willed doughter of a leader of a Polynesian village, who is selected by the blue ocean itself to reunify a mystical relic with a goddess. When a blight attack her island, Moana made a voyage in search of Maui, a legendary demigod, in the hook of returning the hart of the Te Fiti and saving her citizenry.

\section{METHOD}

The study uses mix-method. It is also describe descriptively. The method is used because the writer want to reveal the phenomenon about the flouting maxim in Moana movie. The source of the data is the dialogues in Moana Movie by two main characters they are Moana and Maui. The data taken by the script of conversation Moana and Maui.

\section{RESULTS AND DISCUSSION}

\section{Results}

The data from the main character, Moana and Maui that violated the maxim. The data analyzed are the conversation between Moana and Maui in Moana Movie that flouting maxims.The result can be seen below.

Table 1

The Maxim Relevance

\begin{tabular}{|c|c|c|}
\hline No. & Reasons & The Conversations \\
\hline 1 & & $\begin{array}{l}\text { : Hi, I'm Moana of Motului. You will board my ... Boat. } \\
\text { : A boat. The God has given me...a boat .... }\end{array}$ \\
\hline 2 & & $\begin{array}{l}\text { : Maui. Shape shifter. Demigod of the wind and sea. I am Moana... } \\
\text { : Hero of Man. }\end{array}$ \\
\hline
\end{tabular}




\begin{tabular}{|c|c|c|c|}
\hline 3 & & $\begin{array}{l}\text { Moana } \\
\text { Maui }\end{array}$ & $\begin{array}{l}\text { : What? No, I came here to ... } \\
\text { : Of course, of course. Yes, yes, yes, yes. Maui always has time for his } \\
\text { fans. And use a bird to write with. It's called Tweety. I know, not everyday you } \\
\text { got a chance to meet your hero. }\end{array}$ \\
\hline 4 & The Maui's responses do & $\begin{array}{l}\text { Maui } \\
\text { Moana } \\
\text { Maui }\end{array}$ & $\begin{array}{l}\text { : I can watch that all day. Okay, enjoy the island. Maui... Auww... } \\
\text { : No. Stop ! Hey, you're pull back the horde. } \\
\text { : Did not see that coming. }\end{array}$ \\
\hline 5 & $\begin{array}{l}\text { not appropriate to } \\
\text { Moana's statements }\end{array}$ & $\begin{array}{l}\text { Moana } \\
\text { Maui }\end{array}$ & $\begin{array}{l}\text { : Come for this ... The heart. You mean this heart right here... Come and } \\
\text { get it. } \\
\text { : You are going to get us killed. }\end{array}$ \\
\hline 6 & & $\begin{array}{l}\text { Moana } \\
\text { Maui }\end{array}$ & $\begin{array}{l}\text { No. Have you. } \\
\text { : I'm not going on a suicide mission with some mortal. You can restore the } \\
\text { heart without me. And me says ... No. I'm getting my hook. End of } \\
\text { discussion. }\end{array}$ \\
\hline 7 & & $\begin{array}{l}\text { Moana } \\
\text { Maui }\end{array}$ & $\begin{array}{l}\text { Teach me to sail! } \\
\text { : bhuhhh }\end{array}$ \\
\hline 8 & & $\begin{array}{l}\text { Moana } \\
\text { Maui }\end{array}$ & $\begin{array}{l}\text { : It's cold. Wait, it's getting warmer. Aahh Then it's disgusting. What's } \\
\text { wrong with you? } \\
\text { : hehe }\end{array}$ \\
\hline 9 & & $\begin{array}{l}\text { Moana } \\
\text { Maui } \\
\text { Moana } \\
\text { Maui }\end{array}$ & $\begin{array}{l}\text { : And he lives up there. } \\
\text { : Oh,ho, no, no, no... That's just the entrance. To a Lalotai. } \\
\text { : Lalotai ? Realm of Monsters. We going to the Realms of Monsters. } \\
\text { : We ? No. Me. You are going to stay here with the other chicken. } \\
\text { Bkaaaak. That's what I'm talking about, give me some ... Come on, that } \\
\text { was a good one, how you'd not get it. I called her chicken, that chicken } \\
\text { on the boat. I know she's human, but that's not. You know... forget it. } \\
\text { Forget it, I'm not explaining it to you. What? Cause that is not funny. }\end{array}$ \\
\hline 10 & & $\begin{array}{l}\text { Moana } \\
\text { Maui } \\
\text { Moana } \\
\text { Maui }\end{array}$ & $\begin{array}{l}\text { : My people. Didn't send me. The ocean did. } \\
\text { : The ocean... makes sense, you're what ? Ape. Can't sail. Obvious choice. } \\
\text { : It chose me. For a reason. } \\
\text { : If the ocean so smart. Why didn't just take the heart back to Te Fiti itself. } \\
\text { Or bring me my hook. The ocean straight up pooky dooks. But I'm sure } \\
\text { it's not wrong about you. You're the chosen one. } \\
\text { : The ocean chose you for a reason. } \\
\text { : If you start singing, I'm want to throw up. }\end{array}$ \\
\hline 11 & & $\begin{array}{l}\text { Maui } \\
\text { Moana } \\
\text { Maui }\end{array}$ & $\begin{array}{l}\text { I'm trying to be sincere for once, and it feels you're distracted. } \\
\text { : No, no, no way. } \\
\text { : Really. Cause you looking at me like I have a ... Shark head. }\end{array}$ \\
\hline 12 & & $\begin{array}{l}\text { Moana } \\
\text { Maui }\end{array}$ & $\begin{array}{l}\text { It's not cursed. } \\
\text { : Shark head. }\end{array}$ \\
\hline 13 & & $\begin{array}{l}\text { Maui } \\
\text { Moana } \\
\text { Maui }\end{array}$ & $\begin{array}{l}\text { : What can I say, except we're dead soon. We're dead soon. } \\
\text { : Can't you at least try? } \\
\text { : Giant hook. Hey, it's okay... it's okay. We're dead soon. }\end{array}$ \\
\hline 14 & & $\begin{array}{l}\text { Moana } \\
\text { Maui } \\
\text { Moana } \\
\text { Maui } \\
\text { Moana } \\
\text { Maui }\end{array}$ & $\begin{array}{l}\text { : How do you get your tattoo's. } \\
\text { : They show up when I earn them. } \\
\text { : How do you earn that one. What's that for? } \\
\text { : That's a man's discovery of Nanya, } \\
\text { : What's Nanya? } \\
\text { : Non ya'll Business. }\end{array}$ \\
\hline 15 & & $\begin{array}{l}\text { Moana } \\
\text { Maui }\end{array}$ & $\begin{array}{l}\text { : Maui. You've came back. But your hook. One more hit, and ... } \\
\text { : Te Ka has got to catch me first. I've got your back, chosen one. Go, save } \\
\text { the world. }\end{array}$ \\
\hline 16 & $\begin{array}{l}\text { Moana's response does } \\
\text { not appropriate to } \\
\text { Maui's statement }\end{array}$ & $\begin{array}{l}\text { Maui } \\
\text { Moana } \\
\text { Maui } \\
\text { Moana } \\
\text { Maui } \\
\text { Moana } \\
\text { Maui } \\
\text { Moana } \\
\text { Maui } \\
\text { Moana }\end{array}$ & $\begin{array}{l}\text { Without my hook, I am nothing. } \\
\text { : We are only here because you stole the heart in the first place. } \\
\text { : No, we're here because the ocean told you, You're special and you } \\
\text { believe it, } \\
\text { : I am Moana of Motului. You were board my boat. } \\
\text { : Goodbye, Moana. } \\
\text { : Sail across the sea, } \\
\text { : I'm not killing myself. So you can prove you're something. You're not. } \\
\text { : I just restore the heart of Te Fiti. The Ocean chose me. } \\
\text { : The chose wrong. } \\
\text { : Maui. }\end{array}$ \\
\hline
\end{tabular}

As defined by Maeinborn, 2011) in (Andresen, 2013) that spoken language is one of the most basic ways of human communication. From the table 1 above, number 1 until number 15 show that the Maui's responses do not appropriate to Moana's statements. Moana also does the same response. In table 1 number 16, Moana's response does not appropriate to Maui's statement. 
Although the responses do not appropiate, but they still collaborate their conversation. Thus, the finding is supported by the theory of Philosopher Grice (1975) in Sobhani \& Saghebi, 2014), who propose a conversational theory consisting of the principle of collaboration (hereinafter referred to as $\mathrm{CP}$ ): "Make your conversation contribute as you wish, to the stage in which it occurs, aims or direction of the conversation wherein you are engaged" (A. Sobhani, 2014). The analysis of the data based on Table 1 show that all of conversation can be considered as maxim relevance as explained by Cook (1989) in (Robiatul, 2016). Those sentence on the table 1 proves the communication may contain maxim relevance.

Table 2

The Maxim Manner

\begin{tabular}{|c|c|c|c|}
\hline No. & Reasons & & The Conversations \\
\hline 1 & & $\begin{array}{l}\text { Moana } \\
\text { Maui }\end{array}$ & $\begin{array}{l}\text { : I am Mo ... } \\
\text { : Sorry, Sorry, Sorry, Sorry. And women. Man and women, both all } \\
\text { mothers of Gargoyle thing. Ah, you know, Maui is a hero to all. You'vedoing } \\
\text { great. }\end{array}$ \\
\hline 2 & & $\begin{array}{l}\text { Moana } \\
\text { Maui } \\
\text { Moana }\end{array}$ & $\begin{array}{l}\text { Thank you ? } \\
\text { : You're welcome. } \\
\text { : But, no, no, no. I .. I didn't ... I wasn't ... Why were I ever seen you and you... }\end{array}$ \\
\hline 3 & & $\begin{array}{l}\text { Moana } \\
\text { Maui }\end{array}$ & $\begin{array}{l}\text { : I am Moana of Motului. This is my canoe. And you will journey to } \\
\text { aahh... } \\
\text { : Alright, get over it. We gotta move. And she's back. }\end{array}$ \\
\hline 4 & & $\begin{array}{l}\text { Moana } \\
\text { Maui }\end{array}$ & $\begin{array}{l}\text { : I am Moana of Motul..uiiii.... } \\
\text { : It was Moana, right? }\end{array}$ \\
\hline 5 & $\begin{array}{l}\text { Moana's statements do } \\
\text { not clear }\end{array}$ & $\begin{array}{l}\text { Moana } \\
\text { Maui } \\
\text { Moana } \\
\text { Maui } \\
\text { Moana }\end{array}$ & $\begin{array}{l}\text { : Can't you shift shape or something. } \\
\text { : You see my hook. No magic hook. No magic powers. } \\
\text { : The boat ... is turning into my fault. Yup. I just did best. Maui. They took } \\
\text { the heart. } \\
\text { : That a chicken. } \\
\text { : The heart is in the ... We have to get it back. Mauiii.... There. Right } \\
\text { there! You're turning. }\end{array}$ \\
\hline 6 & & $\begin{array}{l}\text { Moana } \\
\text { Maui } \\
\text { Moana }\end{array}$ & $\begin{array}{l}\text { : Go. } \\
\text { : And he's sticks the landing. What? Dumb-dumb, she's not even here. No } \\
\text { mortals going to jump into the realm of mon... Well.... She's dead. Okay, } \\
\text { let's get my hook. } \\
\text { : Maui's fishhook. } \\
\text { : Yeah.... } \\
\text { : Sorry. I thought you're a monster, but... I find your hook and you're } \\
\text { Right... This tomatoa really like the treasure. }\end{array}$ \\
\hline 7 & & $\begin{array}{l}\text { Maui } \\
\text { Moana }\end{array}$ & $\begin{array}{l}\text { : Stay. } \\
\text { : What } ? \text { No? I'm... I'm the one who... }\end{array}$ \\
\hline 8 & $\begin{array}{l}\text { Maui's response does } \\
\text { not appropriate to }\end{array}$ & $\begin{array}{l}\text { Maui } \\
\text { Moana }\end{array}$ & $\begin{array}{l}\text { : Kakamora. } \\
\text { : Kaka... what? }\end{array}$ \\
\hline 9 & Moana's statement & $\begin{array}{l}\text { Moana } \\
\text { Maui }\end{array}$ & $\begin{array}{l}\text { : If you can talk, you can teach. Way finding. Lesson one ... hit it. } \\
\text { : Pull the sheets. Not the sheets. No. No. No. No. Try that one already. } \\
\text { You're measuring the stars. Not giving the sky hi five. If the current } \\
\text { warm, you're going the right way. }\end{array}$ \\
\hline 10 & $\begin{array}{l}\text { Maui's statement does } \\
\text { not clear }\end{array}$ & Maui & $\begin{array}{l}\text { So...Daughter of the chief. I thought you stayed in the village. You know, } \\
\text { kissing babies and things. Hey, I'm just trying to understand. Why your } \\
\text { people decided to send her. How's my phrases? You. }\end{array}$ \\
\hline
\end{tabular}

Based on Table 2, there are ten conversations that contain of the maxim manner. The conversations number 1 until 7 shows that Moana's statements do not clear. The conversations number 8 and 9 show Maui's responses do not appropriate to Moana's statements. The number 10 shows that Maui's statement does not clear. It is related to Yule's theory which cited in (Winiharti, 2009) that one of a pragmatic imperative in conversation can be called maximmanner. All of the conversations on the table 2 imply the simples; avoid darkness of appearance, keep away from ambiguity, shorten (avoid unnecessary verbosity), and neat.Those conversations are also supported by the theory of Grice as quoted by Grundy (2013) in (Robiatul, 2016) about the cooperative principle. "Logic and Conversation" on 1975 states: "Make your conversation contribution as desired, at a stage where it happens with the goal or 
the way of the conversation in wherein you are involved" by Grice (1975) cited in (Robiatul, 2016). The table 2 explain the logic answers for the utterances which are produced.

Table 3

The Maxim Quantity

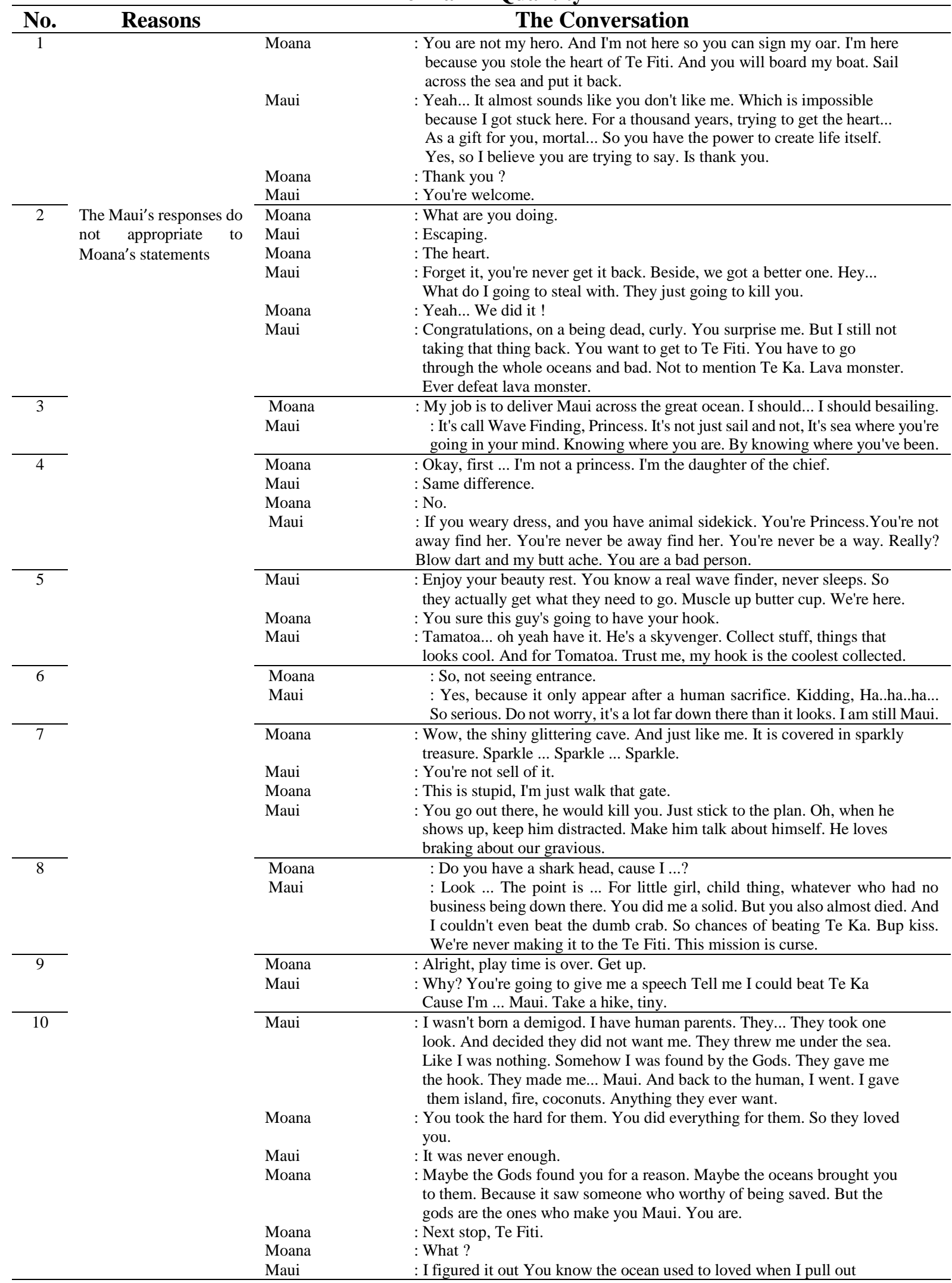




\begin{tabular}{|c|c|c|c|}
\hline & & & $\begin{array}{l}\text { violence. Cause your ancestors would sail the seas. Find them. All those } \\
\text { new island, new villages... It was the water that connected them all. And } \\
\text { byway the ocean. I think I be looking for, ehh... Curly hair, non a } \\
\text { princess. To start that again. }\end{array}$ \\
\hline \multirow[t]{4}{*}{11} & & Maui & : Murdering little pirates. Wonder, what they're here for ? \\
\hline & & Moana & : They're kind of cute. Ocean do something, help us. \\
\hline & & Maui & : The ocean doesn't help you. You help yourself. You can't sail ? \\
\hline & & Moana & : I ... I am soft touch. \\
\hline \multirow[t]{12}{*}{12} & & Moana & : Maui. We got to go. \\
\hline & Moana's responses do & Maui & : Well, what about the heart. \\
\hline & not appropriate to & Moana & : He can have it. I've got a better one. \\
\hline & Maui's statement & Moana & : We're alive. We're alive. \\
\hline & & Maui & : Listen. I appreciate what you did down there. \\
\hline & & Moana & :Mm..hmm... \\
\hline & & Maui & : Took guts. \\
\hline & & Moana & : Mm..hmm... Mm..hmm... Mm..hmm... \\
\hline & & Maui & : But... \\
\hline & & Moana & : Mm..hmm... \\
\hline & & Maui & : I'm sorry. \\
\hline & & Moana & : Mm..hmm... \\
\hline \multirow[t]{2}{*}{13} & $\begin{array}{l}\text { Maui's statement is } \\
\text { flouting the maxim }\end{array}$ & Maui & $\begin{array}{l}\text { : Listen... For a thousand years... I've only been thinking of keeping this ... } \\
\text { getting my hook and being awesome again. And it's not getting screwed up } \\
\text { by a mortal. Who have no business? Inside of monsters cave except ... Except } \\
\text {... Maybe it's bait. }\end{array}$ \\
\hline & & Moana & : Hah.... \\
\hline \multirow[t]{5}{*}{14} & Moana's steatment is & Moana & : I just keep asking. What's that for? \\
\hline & flouting th maxim & Maui & : You need to stop doing that. Back off. \\
\hline & & Moana & : Just tell me what it is? \\
\hline & & Maui & : I said back off. \\
\hline & & Moana & $\begin{array}{l}\text { Is that why your hook not working. You don't want to talked. Don't talk. } \\
\text { You want to throw me off the boat. Throw me off. You want to tell me, I } \\
\text { don't know what I'm doing. I know I don't. I have no idea why the ocean } \\
\text { chose me. You're right. But, my island is dying. So I am here. It's just me } \\
\text { and you. And I want to help. But I can't, if you don't let me. }\end{array}$ \\
\hline
\end{tabular}

Based on the table 3, there are 16 conversations can be concluded as the maxim quantitiy. The reason of number 1 until 10 is the Maui's responses do not appropriate to Moana's statements.

Table 4

\section{The Maxim Quality}

\begin{tabular}{|c|c|c|c|}
\hline No. & Reasons & & The Conversation \\
\hline 1 & & $\begin{array}{l}\text { Moana } \\
\text { Maui } \\
\text { Moana } \\
\text { Maui }\end{array}$ & $\begin{array}{l}\text { : Yes. And you will restore the heart. } \\
\text { : Alright, I'm out. Ahh, come on. } \\
\text { : What is your problem? Are you afraid of it? } \\
\text { : No. No, Ha..ha...ha. I'm not afraid. You stop it. That is not a heart. It is a cursed } \\
\text { the second I took it. I got blasted out of the sky. And I lost myhook. Get it away } \\
\text { from me. }\end{array}$ \\
\hline 2 & $\begin{array}{l}\text { Maui's } \\
\text { contain lies }\end{array}$ & $\begin{array}{l}\text { Moana } \\
\text { Maui }\end{array}$ & $\begin{array}{l}\text { : Get this away. } \\
\text { : Hah .. hey .. hey... I'm Demigod, okay? Stop that, I will } \\
\text { smack you. You want to get smote. Listen, that thing does not give you } \\
\text { power to create life. It's a homing weaken of death. If you don't put it } \\
\text { away bad thing will come for it. }\end{array}$ \\
\hline
\end{tabular}

The result of the research above is the writer found 42 conversation that violated the maximms between main characters, Moana and Maui on Moana movie that violated the maxim. They violated the maxim of quantity, the maxim of quality, the maxim of relevance, and the maxim of manner. We used the formula to calculate percentage of total maxim in National news. In the calculation, we percentage technique as described below:

$$
\mathrm{P}=\mathrm{F} / \mathrm{N} \times 100 \%
$$


Notes :

P: percentage

F: frequent of word (42)

$\mathrm{N}$ : total of word

Table

The classification of Maxim :

\begin{tabular}{|c|c|c|c|}
\hline No. & Types of Maxim & Quantity & Percentage \\
\hline 1. & The maxim of Quantity & 14 & $33,3 \%$ \\
\hline 2. & The maxim of Quality & 2 & $4,8 \%$ \\
\hline 3. & The maxim of Relevance & 16 & $38,1 \%$ \\
\hline \multirow[t]{2}{*}{4.} & The maxim of Manner & 10 & $23,8 \%$ \\
\hline & Total & 42 & $100 \%$ \\
\hline
\end{tabular}

From the classification above, it could be seen clearly that among 4 types of maxim in conversation between the main character, Moana and Maui in Moana movie, the maxim of relevance was the most identifiable type. It number 16 conversation or covers $38,1 \%$. The second was the maxim of quantity, it numbers 14 conversations or covers $33,3 \%$. The third was the maxim manner, it numbers 10 conversation or covers $23,8 \%$. The last one was the maxim of quality, it numbers 2 conversations or covers $4,8 \%$. Those were the violation of each maxim and it numbers. The implied meaning from the conversation were asking to do something, being success to do something, giving surprise and did not want something bad happen to friend.

\section{Discussion}

This study is analized the conversational maxims in Moana movie. The conversational maxim is focused on two main characters they are Moana and Maui. The researchers analized the conversation of Moana and Maui from the script of movie by catagorizing which conversations contain flouting maxim in accordance whit the four floting maxim mentioned by theory of (Yule, 1996). The reason of the researchers choose the Moana movie because in the film contains many statements and responses that are not appropriate, thus that violeted the ruse of the four maxims. By adopting theory from Yuvike and Winiharti, the researchers found many flouting maxims in Moana movie. Many conversation of Moana and Maui which not appropriate with the rules of the maxim. From the analysis among the four maxim is known that flouting maxim more often appear in the Moana movie is the flouting relevance as much as $38,1 \%$ and the least the flouting quality as much as $4,8 \%$.

\section{CONCLUSION}

After conducting the research and collecting the data, the writers can conclude that:

The flouting maxim relevance in Moana movie is the most appear. There were 38,1\%. That among 4 types of maxim in conversation between the main character, Moana and Maui in Moana movie, the maxim of relevance was the most identifiable type. 16 conversations cover $38,1 \%$. The second is the maxim quantity. 14 conversations cover $33,3 \%$. The third is the maxim manner. 10 conversation or covers $23,8 \%$. The maxim quality gets 2 conversations and covers $4,8 \%$. The conclusions are the conversation related to ask to do something, be success in doing something, give surprise and do not want something bad happened to the friend. To 
analized the flouting maxim on Moana movie, the writers watch the movie, and looking for conversation of Moana and Maui script. After that the writers identified and classified the conversation are included into each type of flouting maaxim.

\section{ACKNOWLEDGMENTS}

Alhamdulillahirabbil 'aalamiin. Praise be to Allaah Subhanahu Wa Ta'ala who has enable the writers to finish this research. Peace and salutation are always for Rasulullah Shalallahu 'Alaihi Wasallam. Having completed this research, the writers would like to revealed our thankfulness to all who have given assistance, guidance, and motivation throughout the process of this research.

\section{REFERENCES}

Andresen, N. (2013). Flouting The Maxims In Comedy. Faculty Of Arts And Social Sciences, 29. Retrieved From Http:/Www.DivaPortal.Org/Smash/Get/Diva2:704301/Fulltext01.Pdf

Cook, G. (1989). Discourse. New York: Oxford University Press.

Grice, H. P. (1975). Logic And Conversation Syntax And Semantics (Vol. 3). New York: Academic Press.

Grundy, P. (2013). Doing Pragmatics. New York: Routledge.

Jorfi, L., \& Dowlatabadi, H. (2015). Violating And Flouting Of The Four Gricean Cooperative Maxims In Friends The American Tv Series. International Review Of Social Science, 3(8), 364-371. Retrieved From Http://Irss.Academyirmbr.Com/Papers/1438328398.Pdf

Maeinborn, C. V. (2011). Semantics: An International Handbook Of Natural Language Meaning. Berlin: Walter De Gruyter.

Paltridge, B. (2006). Discourse Analysis: An Introduction. New York: Continuum.

Robiatul, A. (2016). Flouting Maxim Used By The Main Characters In "Focus " Movie Flouting Maxim Used By The Main Characters In "Focus" Movie.

Sobhani, A., \& Saghebi, A. (2014). The Violation Of Cooperative Principles And Four Maxims In Iranian Psychological Consultation. Open Journal Of Modern Linguistics, 4(March), 91-99. Https://Doi.Org/10.4236/Ojml.2014.41009

Thomas, J. (1995). Meaning In Interaction: An Introduction To Pragmatics. United States Of America: Longman.

Winiharti, M. (2009). The Non-Observance Of The Conversational Maxims: An Analysis Of The Dialogues In Arthur Miller's. Lingua Cultura, 3(2), 116-127.

Yule, G. (1996). Pragmatics. New York: Oxford University Press. 